\title{
ВИКОРИСТАННЯ ПРИНЦИПІВ Е-МЕДИЦИНИ В УМОВАХ ДЕРЖАВНО- ПРИВАТНОГО ПАРТНЕРСТВА В РЕАБІЛІТОЛОГІЇ. ПОСТАНОВКА ЗАВДАННЯ
}

\author{
О. П. Мінцер, Н. О. Сінєнко ${ }^{1}$, П. П. Ганінець ${ }^{2}$, \\ О. В. Сарканіч ${ }^{2}$ А. В. Семіволос ${ }^{3}$, О. О. Ярошенко \\ Національна медична академія післядипломної освіти імені П. Л. Шупика \\ ${ }^{1}$ Міністерство охорони здоров'я України \\ ${ }^{2} \mathrm{TOB} \mathrm{«Сузір'я»}$ \\ ${ }^{3}$ Амбулаторно-поліклінічний заклад «Київський міський дитячий \\ діагностичний центр»
}

\begin{abstract}
Розглянуто можливості та реальність вирішення завдань е-медицини за допомогою технологій державно-приватного партнерства (ДПП) в реабілітології. Показано, що застосування технологій е-медицини є одним із найважливіших важелів підвищення якості надання медичної допомоги під час реабілітаційного періоду лікування населення. Постулюється, що оскільки інформатизація охорони здоров'я є дороговартісним проектом, її швидка реалізація можлива за умови максимально широкого використання принципів ДПП. Вважається, що мобільна медицина є найкращим прикладом сучасного ДПП. Запропоновано для ефективного контролю якості надання медичної допомоги населенню створення спеціалізованих експертних і консультативно-дорадчих груп фахівців. Визначено загальні принципи впровадження е-медицини в реабілітології в форматі ДПП.
\end{abstract}

Ключові слова: е-медицина, державно-приватне партнерство, реабілітологія, мобільна медицина, інформаційно-комунікаційні технології.

\section{ИСПОЛЬЗОВАНИЕ ПРИНЦИПОВ Е-МЕДИЦИНЫ В УСЛОВИЯХ ГОСУДАРСТВЕННО-ЧАСТНОГО ПАРТНЕРСТВА В РЕАБИЛИТОЛОГИИ. ПОСТАНОВКА ЗАДАЧИ}

\author{
О. П. Минцер, Н. А. Синенко ${ }^{1}$, П. П. Ганинец ${ }^{2}$, \\ А. В. Сарканич ${ }^{2}$, А. В. Семиволос ${ }^{3}$, А. А. Ярошенко \\ Национальная медицинская академия последипломного образования имени П. Л. Шупика \\ ${ }^{1}$ Министерство здравоохранения Украины \\ ${ }^{2} \mathrm{OOO}$ «Сузирья» \\ ${ }^{3}$ Амбулаторно-поликлиническое учреждение «Киевский городской \\ детский диагностический центр»

\begin{abstract}
Рассмотрены возможности и реальность решения задач е-медицины с помощью технологий государственночастного партнерства (ГЧП) в реабилитологии. Показано, что применение технологий е-медицины является одним из важнейших рычагов повышения качества оказания медицинской помощи во время реабилитационного периода лечения населения. Постулируется, что поскольку информатизация здравоохранения является дорогостоящим проектом, ее быстрая реализация возможна при условии максимально широкого использования принципов ГЧП. Считается, что мобильная медицина представляет собой лучший пример современного ГЧП. Предложено для эффективного контроля качества оказания медицинской помощи населению создание специализированных экспертных и совещательных групп специалистов. Определены общие принципы внедрения е-медицины в реабилитологии в формате ГЧП.
\end{abstract}

Ключевые слова: е-медицина, государственно-частное партнерство, реабилитология, мобильная медицина, информационно-коммуникационные технологии.

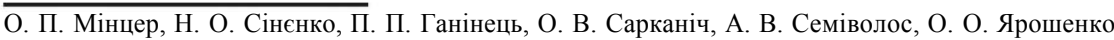




\title{
USING THE PRINCIPLE OF E-MEDICINE IN TERMS OF STATE-PRIVATE PARTNERSHIP IN REHABILITATION. PROBLEM STATEMENT
}

\author{
O. P. Mintser, N. O. Sinyenko ${ }^{1}$, P. P. Haninets ${ }^{2}$, \\ O. V. Sarkanich ${ }^{2}$, A. V. Semivolos ${ }^{3}$, O. O. Yaroshenko \\ Shupyk National Medical Academy of Postgraduate Education \\ ${ }^{1}$ Ministry of health care of Ukraine \\ ${ }^{2}$ "Suzir'ya» Ltd \\ ${ }^{3}$ Ambulatory-policlinic establishment is the "Kyiv municipal child's diagnostic center»
}

\begin{abstract}
The possibilities and reality of e-medicine problems solving with state-private partnership (SPP) technology in rehabilitation are considered. It is shown that the use of e-medicine is one of the most important levers of improving the quality of medical care during the period of rehabilitation treatment. It is postulated that as the healthcare informatization project are expensive its fast implementation is possible provided the widest use of the principles of SPP. It is believed that mobile medicine is the best example of modern SPP. For effective control of medical care quality the creation of specialized expert and advisory group of specialists is offered. The general principles of e-rehabilitation medicine implementing in the SPP format are defined.
\end{abstract}

Key words: e-medicine, public-private partnership, rehabilitation, mobile medicine, information and communication technology.

Вступ. Останніми роками набуло широкого розповсюдження державно-приватне партнерство (ДПП) - ефективна формула підвищення ефективності народного господарства шляхом формування співпраці між приватними партнерами та державою [14]. В Україні останнім часом виконано велику кількість систематизованих досліджень щодо ДПП та його використання в охороні здоров'я, науці, освіті $[4,6]$.

Підсумовуючи особливості застосування ДПП в охороні здоров'я, медичній і фармацевтичній науці та освіті останнім часом, слід зауважити, що набуває високої актуальності пошук принципово нових моделей інтеграції держави, практичної медицини, науки, освіти та бізнесу $[5,11]$. Саме для цих напрямів найбільш значущим стає диверсифікація джерел фінансування науково-дослідних робіт, виробничих технологій (договори з суб'єктами господарювання, реалізація наукових розробок, наукове консультування, експертиза, інформаційні послуги тощо). Очевидно, що диверсифікація фінансування процесів інтеграції медицини, науки та бізнесу сприяє стійкому попиту на виробничотехнологічні інновації.

Особливий інтерес $є$ до цієї форми при впровадженні інформаційно-комунікаційних технологій (ІКТ). Останні знаходять саме широке розповсюдження в усьому світі та дозволяють модернізувати всі галузі народного господарства [2, 3].

Отже, одним із перспективних напрямів підтримки процесів надання медичної допомоги населенню та інтенсифікації інноваційного процесу $\epsilon$ розвиток територіальних науково-виробничих систем - наукових парків, інноваційних технологічних центрів, інкубаторів нововведень тощо.

Мета дослідження: оцінити можливість реалізації сучасного інструментарію ДПП в охороні здоров'я на прикладі створення науково-лікувального та освітнього центру «Приватний санаторій «Сузір'я» - Національна медична академія післядипломної освіти імені П. Л. Шупика». Виявити особливості застосування електронної медицини (е-медицини) в реабілітології та сформувати стратегічні цілі та вектори розвитку е-медицини в умовах ДПП.

Матеріали та методи дослідження. Використано дані періодичних юридичних, економічних i медичних наукових видань України та країн СНД із питань організації, функціонування, видів та нормативно-правового забезпечення ДПП та інформаційно-комунікаційних технологій, їх використання в сфері охорони здоров'я, першою чергою, в реабілітології.

Результати та їх обговорення. Основні проблеми впровадження ДПП пов'язані 3 формуванням механізму ідентифікації, погодження та взаємопов'язаності реалізації на довгостроковій основі інтересів учасників ДПП, блокуючи (обмежуючи) можливості їх опортуністичних дій. Такий механізм повинен забезпечити участь приватного бізнесу на стадіях розроблення та реалізації проектів ДПП, доступність інформаційних ресурсів про цілі, обсяги та структуру ресурсів, що їм виділяють (фінансові, майнові тощо), інструменти наданої 
підтримки, дію моніторингу результатів ДПП 3 оцінкою ефектів, що досягаються його сторонами. Однією з найбільш послідовних концепцій, що розвивають цю ідею, є теорія «сервісної держави», завдання якої полягає в наданні послуг населенню. В даній концепції відбувається руйнування ієрархічних зв'язків, посилюються горизонтальні зв'язки між відомствами. Центр ваги при прийнятті рішення переноситься на інституціональний (регіональний) рівень. Саме тому в рамках цього напряму стають вкрай актуальними процеси інтеграції. Однак мають бути чітко окреслені й стратегії, які орієнтують сторони ДПП на формування конкурентного потенціалу, що забезпечує експансію на нові ринки послуг.

Пріоритетними напрямами ДПП є інноваційно орієнтовані інфраструктурні проекти, а також проекти в сфері охорони здоров'я та освітній сфері. ДПП у такому разі зводиться до трансферу нових знань бізнесу для впровадження в наукоємне виробництво чи надання послуг населенню.

Окрім того, освітні установи отримують додаткове багатоканальне фінансування наукових розробок і доведення їх до комерційного рівня 3 патентуванням і закріпленням авторських прав, формування нової моделі інтегрованого освітнього комплексу, апробації сучасних моделей навчально-наукової та лікувальної практики, розвитку конкурентоспроможності ринку освітніх послуг.

Важливим прикладом застосування принципів ДПП для впровадження е-медицини можуть стати технології мобільної медицини (М-медицини), персоніфікованої медицини тощо [1]. Вони не тільки вкрай економічні та зручні, але й можуть стати вигідним для приватних партнерів.

Е-медицина знайшла своє широке застосування також в напряму, що отримав назву М-медицина. Сьогодні в усьому світі друкуються результати десятків досліджень, що присвячені цьому напряму [12, 13, 21, 23]. Важливо підкреслити, що М-медицина реально претендує на роль лідера і в напряму ДПП. Мобільні пристрої на кшталт смартфонів - комерційний продукт, що необхідний населенню для реалізації щоденних потреб [7, 9, 10 , 22]. Медична ж складова може бути теоретично i практично безкоштовна та направлена на покращання здоров'я населення.

Розглянемо перспективні напрями додатків М-медицини в реабілітології.

Так, клінічна дерматологія є ідеальною моделлю для демонстрації ефективності використання
М-медицини як із погляду впровадження нових технологій, так і напрямів ДПП. Напрями М-медицини в дерматології можуть включати моніторинг стану пацієнтів (особливо при потенційно злоякісних і хронічних ураженнях шкіри), що спирається на використання об'єктивних показників і кількісних факторів ризику. Наприклад, було показано високу чутливість і специфічність мобільного додатку «Іеіесіегтозсору» для оцінки та моніторингу потенційно злоякісних уражень шкіри $[16,18,20]$. Ефективними виявилися технології використання смартфонів для моніторингу стану ран, зокрема у пластичній хірургії, для оцінки стану опіків і післяопераційних рубців [15]. У більшості випадків дослідження свідчили, що з мінімальним додатковим навчанням медичні працівники (неспеціалісти - лікарі в навчальних закладах, медичні сестри, суміжні медичні працівники) можуть забезпечити виконання простих завдань з отримання та аналізу зображень.

Другим класичним медичним напрямом застосування М-медицини вважається офтальмологія [8]. Запис відео (чи фотографування) є важливим компонентом для документування хірургічних i клінічних деталей. Крім того, відеозаписи виконують важливу роль в передачі навичок та демонстрації нових процедур [19]. Застосування мобільних пристроїв збільшило також потенціал для сприяння своєчасної діагностики та прискорення управління лікування захворювань ока в загрозливих умовах. Так, у світовому масштабі рефракція залишається основною причиною всіх порушень зору. Продемонстровані комерційно доступні адаптери щілинної лампи для забезпечення адекватної якості зображення в передній камері ока. 3 огляду на те, що в смартфонах якість зображення камер щорічно підвищується, можна припустити, що в найближчому майбутньому вони зможуть забезпечити високоякісне зображення очного дна.

Незважаючи на зростаючий обсяг літератури 3 М-медицини, недавні метааналізи показали, що на даний час $є$ лише відносно невелика частина застосувань мобільних пристроїв, які забезпечують високу методологічну якість. В інших випадках відсутні об'єктивні клінічні результати. Серед досліджень 3 аналогічними втручаннями виявляється гетерогенна неоднорідність. Крім того, більшість досліджень проведені в країнах з високим рівнем доходу. Це обмежує ступінь, в якій результати можуть бути контекстуалізованими в умовах обмежених ресурсів, де позиціонується М-медицина, щоб забезпечити найбільший лікувальний вплив. 
$€$ ще один важливий проект, пов'язаний з розумінням М-медицини в Україні, — це проект, спрямований на розвиток телемедицини шляхом інтеграції передового медичного досвіду та сучасних телекомунікаційних технологій. Основною метою вважається забезпечення пацієнтів дистанційною доступною високо спеціалізованою медичною допомогою, що має першорядне значення для хворих, які приїжджають на відпочинок в санаторно-курортні заклади. Безумовно, це найкращим чином реалізує наступність медичних дій.

Зрозуміло, що в такому разі учасниками ДПП мають бути створені спеціалізовані експертні та консультативно-дорадчі механізми 3 суворо визначеними принципами функціонування. Вони сформовані нами таким чином.

Принцип об'єктивності означає необхідність дотримуватися вимог об'єктивних закономірностей сталого розвитку, керуватися даними наукового аналізу управлінської ситуації, враховувати реальні можливості суб'єктів партнерської взаємодії, а також здійснювати постійний моніторинг і коригування реалізації проектів у межах ДПП.

Принцип комплементарності конкретизується у принципах орієнтації на згоду, взаємної вигоди, спільної відповідальності і означає, що узгоджуючи навіть протилежні, на перший погляд, інтереси і йдучи на певні самообмеження, партнери досягають більшого результату, ніж кожен із них міг би досягнути самостійно.

Принцип законності, який означає верховенство права, спрямований на формування належного правового поля ДПП і обумовлює необхідність законодавчого визначення його засад. 3 принципом законності безпосередньо пов'язані принципи правової захищеності договірних умов ДПП і правової впорядкованості процесу його здійснення.

Принцип самоорганізації - в його основі лежить здатність системи забезпечити адекватну реакцію на зовнішні впливи з метою досягнення своїх цілей, а також розуміння того факту, що партнерство $\epsilon$ однією 3 найбільш адекватних відповідей на сучасні виклики.

Нарешті, ДПП фактично неможливе без недотримання принципу соціальної відповідальності, тобто відповідальності структур надання медичної допомоги за наслідки своєї діяльності, їхної готовності брати на себе певні зобов'язання та виконувати їх.

У реабілітології має функціонувати ще один принцип - збереження ідентифікуючої інформації щодо стану пацієнта. По суті, йдеться про використання методів спрямованого пацієнт-орієнтованого лікувально-діагностичного впливу, на основі врахування впливів середовища, генетичних та регіональних чинників [17]. Він дозволяє виділити індивідуальні особливості кожного пацієнта, генетичний прогноз ризиків, забезпечити реалізацію концепції персоніфікованої або предикативної (попереджувальної) медицини, що здатна істотно підвищити якість лікування. Одним із нових факторів подібної стратегії є виявлення, оцінка, моніторинг та визначення ступеня впливу ризиків погіршення стану. Обгрунтування ризиків проводиться на базі вже згаданих характеристичних симптомів, які складаються не 3 загальної великої кількості всіх показників, а з особливостей динаміки показників, що унікальна для кожного пацієнта. Зрозуміло, можливо розглядати й динаміку показників при фармацевтичному навантаженні або під час лікувальних процедур. Однак, дотепер не розроблені коректні методики оцінки динаміки факторів ризику в часі, що придатні для клінічної практики. Певною мірою таке положення обумовлене великою кількістю факторів ризику, що становлять сотні, навіть якщо враховувати тільки широко відомі й поодинокі етапи дослідження.

Вважаємо за необхідне зробити ще одне важливе зауваження. На досить великому проміжку часу реабілітації пацієнтів з'являється можливість повернення до стану повного здоров'я чи стійкого стану, збалансованого $з$ навколишнім середовищем. Саме в цей період корекції патологічних зсувів можливий детальний аналіз хвильових процесів в організмі з відповідними трендами на часових графіках.

\section{Висновки.}

1. Е-медицина-один із найважливіших важелів підвищення якості надання медичної допомоги населенню України. Визначено принципи реалізації проектів е-медицини в реабілітології у форматі ДПП.

2. Телемедицина в реабілітології створює великі перспективи в плані забезпечення наступності діагностичних і лікувальних дій шляхом забезпечення постійної комунікації між пацієнтом, сімейним лікарем і фахівцями реабілітаційних служб. 


\section{Література.}

1. What is e-Health (2): The death of telemedicine? Journal of Medical Internet Research, 22.06.01. - Режим доступу: http://www.jmir.org/2001/2/e22/.

2. Качмар В. О. Напрямки розвитку інформаційних технологій у медицині / Качмар В. О., Авраменко В. I. // Медицина транспорту України. - 2011. - № 3. - C. 96-103.

3. Панченко О. А. Медицина и интернет / Панченко О. А., Лях Ю. Е., Антонов В. Г. - Донецк: СПД Дмитренко, 2008. - 524 с.

4. Узунов Ф. В. Класифікація форм державно-приватного партнерства // Інвестиції: практика та досвід. - 2013. - № 17. - С. 113-115.

5. Узунов Ф. В. Покращення розвитку державноприватного партнерства в галузях інфраструктури України // Інвестиції: практика та досвід. - 2013. 一 № 16, - С . 138-141.

6. Узунов Ф. В. Пріоритетні галузі розвитку державно-приватного партнерства в Україні // Інвестиції: практика та досвід. - 2013. - № 18. - С. 142-144.

7. Ahmed B. There will be more than 13,000 medical apps in 2012 in Apple Appstore / Medicalopedia. March 12, 2012. - Режим доступу: www.medicalopedia. org/1509/13000-medical-apps-2012-apple-appstore.

8. Bastawrous A. Validation of Near Eye Tool for Refractive Assessment (NETRA) - Pilot Study / Bastawrous A., Leak C., Howard F., Kumar B. // Journal MTM. - 2012. - Vol. 1, No. 3, -P. 6-16.

9. Boulos M. N. K. How smartphones are changing the face of mobile and participatory healthcare: an overview / Boulos M. N. K, Wheeler S., Tavares C., Jones R. // BioMed Eng. OnLine. - 2011. - Vol. 10. - 24 p.

10. Engel H. Remote real-time monitoring of free flaps via smartphone photography and $3 \mathrm{~g}$ wireless internet: a prospective study evidencing diagnostic accuracy / Engel H., Huang J. J., Tsao C. K. et al. // Microsurgery. - 2011. - Vol. 31, No. 8. - P. 589-595.

11. Fitzgerald P. Review of Partnerships Victoria provided infrastructure. Final report to the treasurer/Growth Solutions Group. January, 2004. - Режим доступу: http://www.un.org/esa/coordination/Alliance/ PPPInfrastructure.pdf.

12. Free C. The effectiveness of mobile-health technologies to improve health care service delivery processes: a systematic review and meta-analysis / Free C., Phillips G., Watson L. et al. // PLoS medicine. - 2013. Vol. 10, No. 1. - P. EI001363.

13. Garvin W. The legal perspective of mHealth in the United States // Journal MTM. - 2012. - Vol. 1, No. 4, - P. 42-45.

14. Healing our hospitals: A report on public hospital funding / Commonwealth of Australia. December, 2000. - Режим доступу: http://www.aph.gov. au/Parliamentary_Business/Committees/Senate/
Community_Affairs/Completed_inquiries/1999-02/ pubhosp/report/index.

15. Hsieh C. H. Teleconsultation with the mobile cameraphone in digital soft-tissue injury: a feasibility study / Hsieh C. H., Tsai H. H., Yin J. W. et al. // Plast. Reconstr. Surg. - 2004. - Vol. 114, No. 7. - P. 1776-1782.

16. Huang C. C. Design and implementation of a smartphonebased portable ultrasound pulsed-wave doppler device for blood flow measurement / Huang C. C., Lee P. Y., Chen P. Y., Liu T. Y. // IEEE Trans Ultrason. Ferroelectr. Freq. Control. - 2012,-Vol.59, No. 1, - P. 182-186.

17. Jain K. K. Personalized medicine // Curr. Opin. Mol. Ther. - 2002. - Vol. 4, No. 6. - P. 548-558.

18. Kroemer S. Mobile teledermatology for skin tumour screening: diagnostic accuracy of clinical and dermoscopic image teleevaluation using cellular phones / Kroemer S., Fruhauf J., Campbell T. M. et al. // Br. J. Dermatol. - 2011. - Vol. 164, No. 5. - P. 973-979.

19. Lord R. K Novel uses of smartphones in ophthalmology / Lord R. K, Shah V. A., San Filippo A. N., Krishna R. // Ophthalmology. - 2010. - Vol. 117, No. 6. P. 1274-e3.

20. Massone C. Melanoma screening with cellular phones / Massone C., Hofmann-Wellenhof R., Ahlgrimm-Siess V. et al. // PLoS ONE. - 2007. — Vol. 2, No. 5. - P. e483.

21. Mobile Medical Applications. Guidance for Industry and Food and Drug Administration Staff / U.S. Department of Health and Human Services FDA, Center for Devices and Radiological Health, Center for Biologies Evaluation and Research. February 9, 2015. - Режим доступу: http://www.fda.gov/downloads/Medical Devices/.. ./UCM263366.pdf.

22. Mudanyali O. Integrated rapid-diagnostic test reader platform on a cellphone / Mudanyali O., Dimitrov S., Sikora U. et al. // Lab. Chip. - 2012. - Vol. 12, No. 15. - P. 2678-2686.

23.Perera C. The evolution of E-Health - mobile technology and mHealth // Journal MTM. - 2012. Vol. 1, No. 1. - P. 1-2.

\section{References.}

1. What is e-Health (2): The death of telemedicine? Journal of Medical Internet Research, 22.06.01. — URL: http:// www.jmir. org/2001/2/e22/.

2. Kachmar, V. O., \& Avramenko, V. I. (2011). Napryamki rozvitku informatsiinikh tekhnologii u meditsini [Directions of development of information technologies in medicine]. Meditsina transportu Ukraini (Medicine of Ukrainian transport), 3, 96-103.

3. Panchenko, O. A., Lyakh, Yu. E., \& Antonov, V. G. (2008). Meditsina i internet [Medicine and Internet]. Donetsk: Dmitrenko.

4. Uzunov, F. V. (2013). Klasifikatsiya form derzhavnoprivatnogo partnerstva [Classification of forms of public-private partnership]. Investitsii: praktika ta 
dosvid (Investment: Practice and Experience), 17, 113-115.

5. Uzunov, F. V. (2013). Pokrashchennya rozvitku derzhavno-privatnogo partnerstva $v$ galuzyakh infrastrukturi Ukraini [Improving the development of public-private partnership in the infrastructure of Ukraine.]. Investitsii: praktika ta dosvid (Investment: Practice and Experience), 16, 138-141.

6. Uzunov, F. V. (2013). Prioritetni galuzi rozvitku derzhavno-privatnogo partnerstva $\mathrm{v}$ Ukraini [Priority sectors of development of public-private partnership in Ukraine]. Investitsii: praktika ta dosvid (Investment: Practice and Experience), 18, 142-144.

7. Ahmed, B. (2012, March 12). There will be more than 13,000 medical apps in 2012 in Apple Appstore. Retrieved from Medicalopedia website, www.medicalopedia. org/1509/13000-medical-apps-2012-apple-appstore.

8. Bastawrous, A., Leak, C., Howard, F., \& Kumar, B. (2012). Validation of Near Eye Tool for Refractive Assessment (NETRA) — Pilot Study. Journal MTM, 1(3), 6-16. doi:10.7309/jmtm.17

9. Boulos, M. N. K, Wheeler, S., Tavares, C., \& Jones, R. (2011). How smartphones are changing the face of mobile and participatory healthcare: an overview. BioMed Eng. OnLine, 10, 1-24. doi: 10.1186/1475925X-10-24.

10. Engel, H., Huang, J. J., Tsao, C. K, Lin, C. Y., Chou, P. Y., Brey, E. M., ... Cheng, M. H. (2011). Remote real-time monitoring of free flaps via smartphone photography and $3 \mathrm{G}$ wireless internet: a prospective study evidencing diagnostic accuracy. Microsurgery, 31(8), 589-595. doi: 10.1002/micr.20921

11. Fitzgerald, P. (2004, January). Review of Partnerships Victoria provided infrastructure. Final report to the treasurer. Retrieved from United Nations Public-Private Alliance for Rural Development website, http://www. un.org/esa/coordination/Alliance/PPPInfrastructure.pdf

12. Free, C., Phillips, G., Watson, L., Galli, L., Felix, L., Edwards, P., ... Haines A. (2013). The effectiveness of mobile-health technologies to improve health care service delivery processes: a systematic review and meta-analysis. PLoS medicine, 10(1), el001363. doi: 10.1371/journal.pmed. 1001363.

13. Garvin, W. (2012). The legal perspective of mHealth in the United States. Journal MTM, 1(4), 42-45. doi: $10.7309 / \mathrm{jmtm} .82$

14. Commonwealth of Australia. (2000, December). Healing our hospitals: A report on public hospital funding. Retrieved from http://www.aph.gov.au/Parliamentary_ Business/Committees/Senate/Community_Affairs/ Completed_inquiries/1999-02/pubhosp/report/index

15. Hsieh, C. H., Tsai, H. H., Yin, J. W., Chen, C. Y., Yang, J. C., \& Jeng, S. F. (2004). Teleconsultation with the mobile camera-phone in digital soft-tissue injury: a feasibility study. Plast. Reconst.r Surg., 114(7), 1776-1782.
16. Huang, C. C., Lee, P. Y., Chen, P. Y., \& Liu, T. Y. (2012). Design and implementation of a smartphonebased portable ultrasound pulsed-wave doppler device for blood flow measurement. IEEE Trans Ultrason. Ferroelectr. Freq. Control, 59(1), 182-186. doi: 10.1109/ TUFFC.2012.2171.

17. Jain, K. K. (2002). Personalized medicine. Curr. Opin. Mol. Ther., 4(6), 548-558.

18. Kroemer, S., Fruhauf, J., Campbell, T. M., Massone, C., Schwantzer, G., Soyer, H. P., \& HofmannWellenhof, R. (2011). Mobile teledermatology for skin tumour screening: diagnostic accuracy of clinical and dermoscopic image teleevaluation using cellular phones. Br. J. Dermatol., 164(5), 973-979. doi: 10.1111/j.13652133.2011.10208.x.

19. Lord, R. K, Shah, V. A., San Filippo, A. N., \& Krishna, R. (2010). Novel uses of smartphones in ophthalmology. Ophthalmology, 117(6), 1274-e3. doi: 10.1016/j. ophtha.2010.01.001

20. Massone, C., Hofmann-Wellenhof, R., AhlgrimmSiess, V., Gabler, G., Ebner, C., \& Soyer, H P. (2007). Melanoma screening with cellular phones. PLoS ONE, 2(5), e483. doi: 10.1371/journal.pone.0000483

21. U.S. Department of Health and Human Services FDA, Center for Devices and Radiological Health, Center for Biologies Evaluation and Research. Mobile (2015, February 9). Medical Applications. Guidance for Industry and Food and Drug Administration Staff. Retrieved from http://www.fda.gov/downloads/Medical Devices/.. ./UCM263366.pdf.

22. Mudanyali, O., Dimitrov, S., Sikora, U., Padmanabhan, S., Navruz, I., \& Ozcan, A. (2012). Integrated rapiddiagnostic test reader platform on a cellphone. Lab. Chip., 12(15), 2678-2686. doi: 10.1039/c21c40235a.

23. Perera, C. (2012). The evolution of E-Health - mobile technology and mHealth. Journal MTM, 1(1), 1-2. doi: $10.7309 /$ jmtm.1 